Revista Eletrônica Geografar, Curitiba, v. 2, Resumos do VI Seminário Interno de Pós-Graduação em Geografia, p. 25-25. Junho/2007

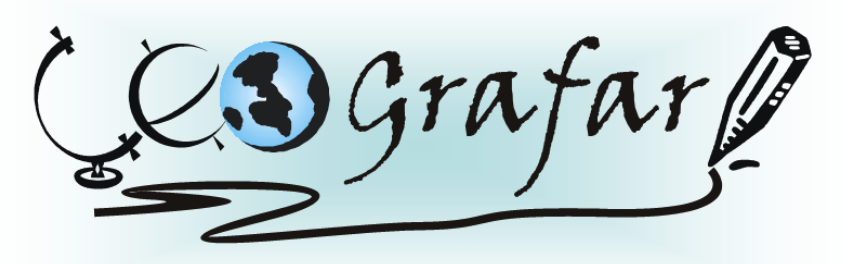

Revista Eletrônica do Programa de Pós-Graduação em Geografia - UFPR

\title{
QUALIDADE AMBIENTAL E ADENSAMENTO NA ÁREA URBANIZADA DO MUNICÍPIO DE PARANAGUÁ NO LITORAL DO PARANÁ
}

\section{EMERSON LUÍS TONETTI ${ }^{1}$}

O Município de Paranaguá concentra praticamente metade da população do litoral do Estado. A taxa média de crescimento anual da população urbana para o período de 1970 a 2000 foi de $2,6 \%$ e a taxa de urbanização em 2000 foi de $96 \%$. Parte do crescimento é resultante de imigrantes, principalmente de outras cidades do Estado do Paraná, provavelmente atraídos pelas atividades portuárias. O Município de Paranaguá atendeu a este crescimento populacional expandindo sua área urbana. Muitos dos locais ocupados são juridicamente irregulares e se localizam em áreas ambientalmente frágeis, gerando problemas diversos. Muitos dos bairros cresceram sem o devido planejamento e sem a implantação dos serviços públicos básicos. Considerando que as restrições espaciais, jurídicas, ambientais e prováveis mudanças das políticas públicas limitem a expansão das fronteiras urbanas do Município de Paranaguá, a tendência será ocorrer um processo de verticalização para atender a demanda por espaço imposta pelo crescimento populacional. Assim, considera-se necessário um estudo da qualidade ambiental, para auxiliar no reconhecimento e na indicação de locais que suportariam um adensamento sem comprometer sua qualidade. Este trabalho, também poderia auxiliar na busca de soluções para melhorar as condições ambientais dos locais com situações desfavoráveis no Município e no estabelecimento de critérios de avaliação da qualidade ambiental para permitir uma maior eficiência das políticas ambientais. O trabalho tem como base teórica o planejamento da paisagem, uma teoria do planejamento que incorpora os princípios geoecológicos na avaliação da potencialidade (limites e aptidões) da natureza e da paisagem para acolher os usos humanos.

Palavras-chave: qualidade ambiental, planejamento da paisagem, Paranaguá.

'Doutorando em Geografia - UFPR - email: emersontonetti@gmail.com Orientador: JOÃO CARLOS NUCCI 